\title{
Environmental Health Condition of Slum Dwellers of ljora-Badia Area of Lagos State, Nigeria
}

\author{
Yussuf Lukeman ${ }^{1}$ \\ Bako, A.I 2 \\ Omole, F.K*3 \\ Nwokoro, I.I.C4 \\ Alakinde, M.K ${ }^{5}$ \\ 1,4 Department of Urban and Regional Planning, University of Lagos \\ 2 Department of Urban and Regional Planning, University of Ilorin \\ 3,5 Department of Urban and Regional Planning, the Federal University of Technology, P.M.B 704Akure, Nigeria
}

Email: fkyomole@yahoo.co.uk

\section{Doi:10.5901/ajis.2014.v3n4p79}

Abstract

It has been established that poverty such as lack of access to clean water, inadequate sanitation, poor waste disposal, indoor air pollution and overcrowding in housing, are the major determinants of environmental health conditions of the slum dwellers. In this paper the relationship between environmental condition and health condition of slum dwellers in ljora-Badia was investigated. Some of the environmental variables were compressed as environmental factors and health condition variables were compressed as health factors. The health factors served as dependent variables while environmental factor served as independent variable and other factors remained constant. Data were collected via questionnaires, personal interview, direct observation and focus group discussion. The research population was based on the total number of existing buildings from which the total numbers of household head were determined and $5 \%$ of the total household head population was taken for the interview. Findings reveal that, environmental condition has direct effect on the health of respondents ("P"value for environmental factors is 0.003 which is less than 0.05) the environment has direct effect on the health condition of dwellers. The better the environment the better the health condition of the dwellers. The paper suggests that while a total clearance of the slum in the study areas may not be feasible because of the cost elements, inconvenience and other logistic problems it might cause. It is evidence from the study that the level of deterioration is still redeemable. Programme like Urban Basic Service (UBS) which encompasses provision of facilities, environmental campaign will not only reduce the environmental health risks of slum dwellers but will also usher in a functional, livable and aesthetically pleasing environment.

Keywords: Environmental health, slum, overcrowding, pollution, diseases, household.

\section{Introduction}

Demographers have long emphasized the contribution of natural increases to urban growth. Reclassification, whereby urban status is conferred on formerly rural residents and territory also deserves consideration. An analysis by Chen et al (1998) reconfirms the 1980 estimates by the United Nations, of the share of urban growth due to migration and reclassification combined at about $40 \%$. The remaining part of urban growth roughly about $60 \%$ is due to urban natural increases. The Chen et al findings underscore the point that both migration and natural increases make substantial contributions to urban growth (Montgomery et al. 2003).

Similarly, poverty has long been associated with the rural masses in developing countries, which have rightly been the targets of development and food assistance programs. With the growth of cities, poverty is increasingly becoming visible among city dwellers to the extent that many urban poor live in absolute poverty. UN Habitat estimates that there are currently 924 million slum dwellers in the world, making up one third of the global urban population. This number could grow to 1.5 billion by 2020 unless a significant health and infrastructure interventions and pro-poor housing and land tenure policies are undertaken. The poor are the fastest growing population in urban areas. A quick look at the absolute numbers of urban poor populations living in the developing region reveals a challenge of staggering proportion. 
As a result, African's cities, already facing significant challenges to targeting these populations with services, will face a greater burden in the coming years. Sixty percent of the world's slums are in Asia. In absolute numbers, Asian slum dwellers outnumber those of any other region, with about 550 million people living in Asian slums. Africa follows with 187 million urban slum residents (UN Habitat 2003). Urban poverty has many facets that need to be considered such as housing as well as levels of income and consumption. Poverty is conventionally defined in terms of incomes that are inadequate to permit the purchase of necessities, including food and safe water in sufficient quantity. In such populations, housing/shelter may be of poor quality, overcrowded or insecure. Inadequate provision of public infrastructure (piped water, sanitation, drainage) can increase health burdens (Montgomery et al. 2003).

Another factor is the lack of voice within the political systems that keep the concerns of the poor from being heard. Information on the health of the urban poor is increasingly becoming unavailable. It is showing large disparities between wealthier and poorer socio-economic groups for such indicators as child mortality, disease morbidity or the burden of illness, wasting and stunting. In some cases, data show that the health of children in urban slums is worse than their rural counterparts, and that the urban poor suffer disproportionately from environmental and infectious illnesses. Diarrheal disease, malnutrition, respiratory illnesses, tuberculosis, neonatal and maternal mortality, HIVIAIDS among others. Key determinants of ill health among the urban poor are lack of clean water, sanitation, and crowding. Solid waste disposal, substandard housing, and exclusion from health and other services exacerbate the situation. The most vulnerable are the small children, women and people whose immune systems are compromised are the most affected. Infectious diseases such as measles, tuberculosis and cholera spread quickly in crowded urban environments. Infectious disease knows no boundary, all areas of the city are threatened. Small children living in urban slums are extra-vulnerable. It is likely that poverty-related differences in children's health are due, in part, to differences in access to services. If poor households have worse access to sanitation and clean water, children in those households may be at greater risk of exposure to communicable diseases, in particular diarrheal diseases. The purpose of this research work is to critically look at the relationship between environmental conditions and health conditions of slum dwellers with reference to ljora-Badia in Lagos, Nigeria.

\section{The Study Area}

ljora- Badia is one of the blighted area identified by UNDP which was also validated by the consulting firm SNC-Lavalin employed by Lagos State Government in the World Bank assisted Infrastructure Upgrading programme for metropolitan Lagos (UNDP,1997).

Lagos is regarded as a mega city, because its population is estimated to be about 18 million people, with a population density of 20,000 persons/sq $\mathrm{km}$ (Mabogunje, 2002). Lagos state is on a built-up land area of about 18,558 Hectares, of which made up of about 9,669 hectares $52.1 \%$ is residential, commercial, 1,021 hectares (5.5\%); industrial, 1,448 hectares (7.8\%); institutional and special areas, 2,784 hectares (14\%); transportation 3,340 hectares (18\%), and open spaces 52 hectares (2.8\%). The Lagos metropolis comprises $88.7 \%$ of Lagos State (Lagos State Economic Summit (2001).

The Lagos Metropolitan area with an area of 3557 square kilometers is defined as the continuous built-up area of Lagos, starting from the Atlantic Ocean in the south and spreading eastwards, westwards, and northwards. It includes eighteen of the twenty Local Government Areas of Lagos State and, another, four Local Government Areas of Ogun State. The vast territory of the Mega City is identified as covering 10 kilometers beyond the Lagos-Ogun State boundaries into Ogun State. In collaboration with Mabogunje (2002), Lagos state has a population of 17 million, out of a national estimate of 150 million. The UN estimates that at its present growth rate, Lagos state will be third largest mega city in the world by Year 2015 after Tokyo in Japan and Bombay in India. The rate of population growth is about 600,000 per annum with a population density of about 4,193 persons per sq. km. In the built-up areas of Metropolitan Lagos, the average density is over 20,000 persons per square $\mathrm{km}$. Of this population, Metropolitan Lagos, an area covering $37 \%$ of the land area of Lagos State is home to over 85\% of the State population (NPC, 2006).

The study is set in the Lagos Metropolis, Lagos State, South Western Nigeria. Lagos Metropolis is situated within latitudes $6^{\circ} 23^{\prime} \mathrm{N}$ and $6^{\circ} 41^{\prime} \mathrm{N}$ and longitudes $2^{\circ} 42^{\prime} \mathrm{E}$ and $3^{\circ} 42^{\prime} \mathrm{E}$. It comprises settlements that have grown from predominantly farming and fishing villages to highly urbanized settlements. Lagos Metropolis is bounded in the west by Ojo and ljanikin, Lekki Peninsula in the east and Ikorodu and Alagbado towns in the north.

The specific area of study ljora- Badia, one of the suburbs in the Apapa Local Government of Lagos State and it is located in the Southern fringe of the Lagos Metropolitan area. It is situated at the interaction point of the geographical latitude $3^{\circ} 23^{\prime}$ and longitude $4^{\circ} 22^{\prime}$. It is bounded in the North by the Lagos Badagry expressway link bridge into the 
National Theatre. A railroad to Apapa forms the Eastern boundary. The South is bounded by Ajegunle another lowincome residential suburb.

\section{Literature Review}

A healthy home is not a specially designed house, it is more a residential setting for household that is including all standards and best practice knowledge that has gained over centuries of dwelling construction and immediate environment design. Healthy housing means more than a roof over one's head. It also means adequate privacy; adequate space, physical accessibility, adequate security, security of tenure, structural stability and durability, adequate lighting, heating and ventilation, adequate basic infrastructure facilities, suitable environmental quality and health related factors, and adequate and accessible location with regards to work and basic facilities; all of which should be available at an affordable cost (Agbola, Nwokoro and Kassim 2007).

Desirably residential environment (homes, Neighborhood and communities) should play an important role in determining individuals' well-being. The World Health Organisation (WHO) reckons that it is the home, not the clinic that is the key to a better healthy delivery system. However, in the developing countries according to Nwaka (2005), only about 25 to 30 percent inhabitants, mainly top government officials and other rich and privileged people in the society enjoy decent quality housing. The vast majority of households especially those in informal settlements, live in overcrowded conditions, within defective physical dwellings sometimes located on areas which did not provided defense against diseases and other health or hazards because many people do not have secure tenure with respect to land and houses they occupy. They have little inclination to improve the quality of the houses and the general environment due to constant threats of forced eviction. Therefore, housing and the quality of housing significantly impact on health. Poor housing condition will invariably lead to variety of health problem which includes scabies, asthma, malaria, diarrhea, depression, stress, respiratory diseases, influenza, tuberculosis, meningitis, lead poisoning, and HIVIAID pandemic among others.

In the late 1970s, Murphy (2004), narrated how the International health leaders gathered to ponders on what the health of the World would look like in year 2000. The leader crystal ball showed vast improvements and essentially healthy population all over the world. In other words, in a little over 25 years (from the mid $20^{\text {th }}$ century) global public health efforts had met with enormous success in diseases control and even total eradication of smallpox, one of the world's worst health scourges. In addition, infant and child mortality had dropped in the face of massive campaigns, food supplements and new treatment of common illnesses. With this development, health professionals felt that given the will in terms of political resolve and adequate resources, the world would be transferred into healthy place in the $21^{\text {st }}$ century. Nwaka (2005), pointed out that available evidence are there to show that, in spite of overall progress, good housing and healthy living elude billions of people. Many factors have intensified and brought about the development of squatter, slum and informal settlement characterized by poor housing conditions.

The basic causes includes the high demand for housing in the wake of rapid rural-urban migration, the slow growth of the housing stock coupled with the low incomes of the majority of the rural migrants and abject poverty. Thus for many Africa residents, the choice of where to live is almost predetermined. They cannot afford the cheapest low cost housing; therefore, they live in unhealthy locations such as low-lying and marginal lands that lack basic infrastructural facilities and services such as clean water and sanitation. Poverty in the developing countries is the most important determinant of poor health. Carr (2004) observed that more than 1 billion people are living on less than one dollar a day and one of every six people worldwide, lack basic infrastructural especially improved water, sanitation and housing are out of reach; while many initiative that tried to improve the health of people living in unhealthy conditions and in extreme poverty have failed. Poverty dominates the international development agenda of the $21^{\text {st }}$ century.

The improvement of the health and living conditions of millions of slum dwellers around the world is a primary concern of the current Millennium Development Goal for reducing poverty. Up to the 1980s, poverty was largely associated with the rural areas in developing countries; but the situation has changed with the dramatic increase in the number and proportion of the population living in urban areas, and a corresponding increase in the level of urban poverty. Consequently, irregular settlements have become so pervasive that they seem to outnumber legally planned development, and their social legitimacy appears to be no longer in questions. Unfortunately, the appalling environmental and housing condition associated with informal settlement constitutes a major threat to the health and well being of urban life. Depending on the individual countries and cities, between 40 to 80 percent of urban dwellers in the world are living in poverty with very little or absolutely no access to shelter, basic infrastructural services and social amenities.

Agbola (2005), reports in his work that rapid urbanization, is an offshoot of rural-urban migration in the last five 
decades has profound effects on socio economic changes and living condition. This has caused the burgeoning of new kind of squatter and informal housing all around the rapidly expanding cities in the developing countries. The burgeoning and expanding cities have been confronted with colossal environmental problems of matching the provision of urban infrastructural facilities and services with their levels of demand. In addition, supply in the area of water, electricity, transport, education, housing, and health, more often than not, falls short of demand. Thus the indices of overcrowding, inadequate water supply and sanitation, infectious diseases, various types of civil and violent crime are obvious and perhaps more despairingly Problems of slum areas.

For a long time successive post-colonial administrations appeared to see the growing urban problems "with the jaundiced eye of defenders of a colonial legacy". The Nigerian Town and Country Planning Ordinance of 1946 remained essentially unchanged until 1992, not because it was working satisfactorily but because it was largely ignored and bypassed by the rapid growth and spontaneous development. Most of the laws and regulations guiding environmental health and sanitation appear to be reminders of colonial segregation and oppression, and have very little current relevance. For instance, residential areas are also now widely used for small businesses, in complete disregard of the zoning arrangements which require separate areas for presumed incompatible activities. As was typical with the military, the Nigerian Land Use Decree was introduced in 1978, ostensibly to facilitate speedy and equitable access to land for much needed planned development. The proprietorship and control of all land was vested in the state. Various land allocation and advisory committees were set up to assist the state governors in the administration of land. In practice, the procedure for obtaining and developing land become excessively bureaucratized, obstructive, and riddled with corruption. Restrictions on the availability of land, especially for the poor, encouraged the growth of more and more irregular settlements on the fringes of the towns or on vacant public land.

With respect to housing, Nigeria experimented with virtually all of the approaches that were fashionable in the 1960s, 1970s, and 1980s slum clearance schemes which caused much distress and social dislocation, sites-and-services schemes which tried to open up new land and have it subdivided into serviced residential plots for distribution, and slum or squatter upgrading which tried to fit new infrastructure and services into already disorderly and crowded settlements, sometimes with the participation of local residents. Also, following Habitat I in 1976 and the oil boom of the 1970s and early 1980s, Nigeria embarked on an ambitious program of public housing construction. The federal government planned to add over 200,000 housing units to the existing housing stock, while the state governments at the time would each build an additional 4,000 housing units. Mortgage facilities were established and a new government ministry was created for Housing, Urban Development, and the Environment, FMHUDE. Typically, only about $12 \%$ of the projected housing targets for $1970-74$, and $24 \%$ for $1975-1980$ was actually achieved. The enormous resources earmarked for the purpose were misappropriated or otherwise diverted to the construction of military barracks and other projects of doubtful priority. None of the housing programs advanced the housing conditions or needs of the poor in irregular settlements, but instead provided subsidized housing for middle-income groups, high-income people, and other well-connected individuals.

These are stories of failure and plateform of slum development in Nigeria, which are off shoot of poor environment and health condition.

\section{Methodolgy}

In order to investigate the relationship between environmental conditions and health conditions of slum dwellers in Badia Lagos, Nigeria, the study embraces both primary and secondary sources of information. These were obtained from the field through the use of research instrument such as administration of questionnaires, personal interviews, observations and focus group discussion. Secondary information were collected from reports, (published and unpublished sources), textbooks, journals, file of government agencies and parastatals. These includes the National Population Commission, the local government, and the Internet among many others.

There are 539 residential buildings in ljora-Badia, Lagos (Tenement Rate Department Apapa Local Government, 2011). It has an average of minimum 7 households in a building, being a high residential area of the metropolitan Lagos. Since, the minimum average households per building is 7 households, the targeted population household in the study area translate to $539 \times 7=$ three thousand seven hundred and seventy three $(3,773)$ households. The targeted household population of this study is 3,773 and the sample size is $5 \%$ of the targeted household population which translate to one hundred and eighty nine (189) and this becomes the total number of questionnaires administered for the study. In each district in the study area, 5\% sample size were considered reasonable for this study, because of the homogeneous characteristics that was peculiar to the residents in the study area.

The research adopts multi stage sampling technique in the research procedure. First stage is the delineation and 
dividing ljora-Badia into three districts, namely; ljora-Badia West, ljora-Badia central, and ljora-Badia East (Onyeche, 2011). Second stage is the identification of the buildings in each of the district by systematic sampling technique. All buildings in each district were arranged serially, from which the sampled buildings were selected. The $3^{\text {rd }}$ building forms the nth term while every $3^{\text {rd }}$ building was sampled from each district.

A randomly sampling technique was adopted in the third stage for the selection of household head sampled. This sampling method was based on household size in selected residential building. Household with highest number of people was selected. Finally, in each of the districts, questionnaires were administered systematically and randomly selection of household head on every $3^{\text {rd }}$ buildings in each district. The questionnaires were administered according to the number of buildings in the study area.

Table 1: Distribution of questionnaires within the district in the study area (ljora-Badia).

\begin{tabular}{|l|c|c|}
\hline Name of district & Number of Buildings in each District & Number of Questionnaires Administered \\
\hline ljora-badia West & 129 buildings & 45 \\
\hline ljora-badia Central & 230 buildings & 81 \\
\hline ljora-badia East & 180 buildings & 63 \\
\hline Total & 539 Buildings & 189 \\
\hline
\end{tabular}

Source: Tenement Rate Department, Apapa Local Government (2011) and sample size by the authors.

\section{Research Findings}

The table 2 gives detailed of chi-square analysis that explained the relationship between the environmental conditions and health status of slum dwellers.

Table 2: Cross-tabulation of health facilities patronized by the dwellers and household Income per month

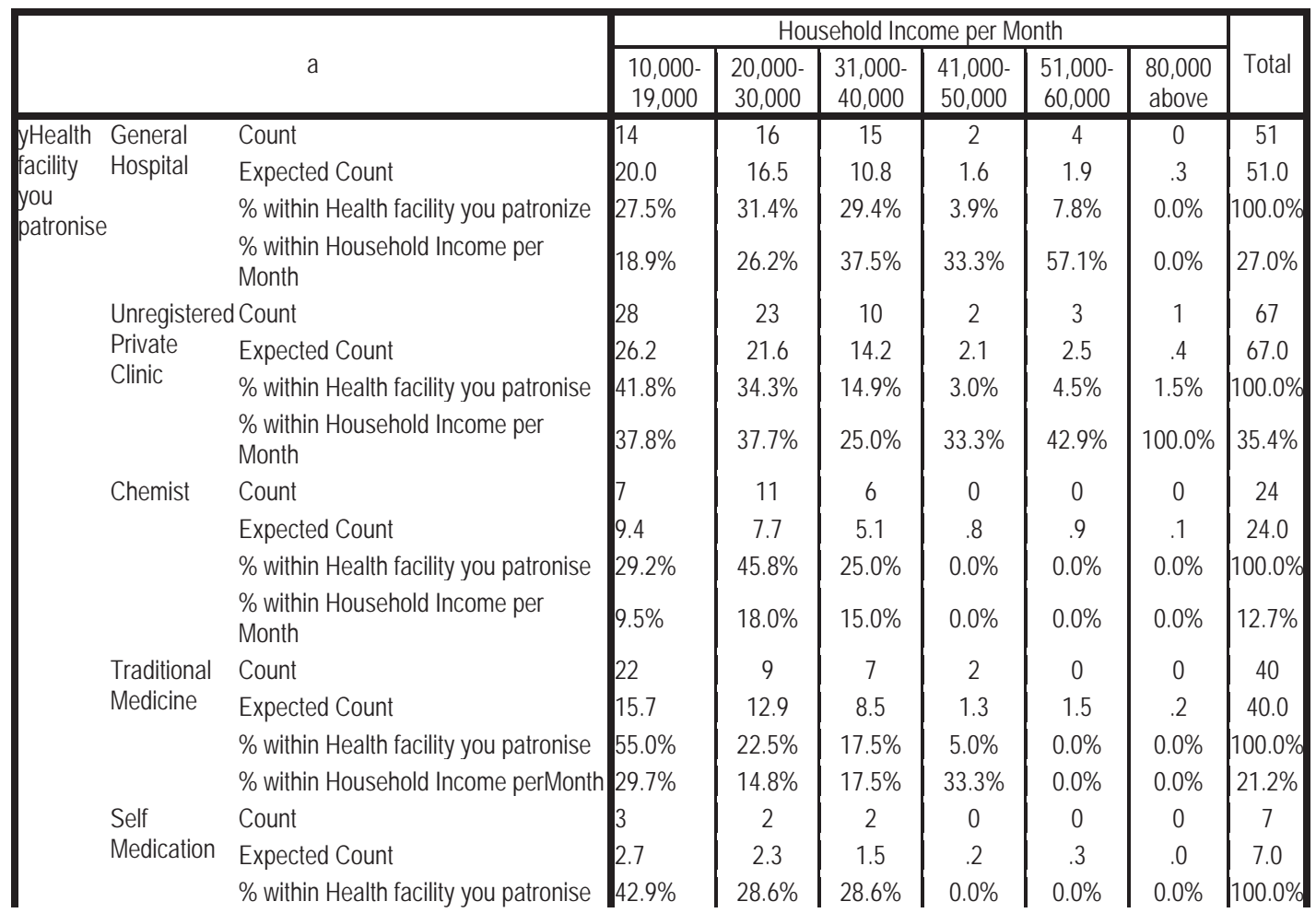




\begin{tabular}{|ll|l|c|c|c|c|c|c|}
\hline & \% within Household Income per & $4.1 \%$ & $3.3 \%$ & $5.0 \%$ & $0.0 \%$ & $0.0 \%$ & $0.0 \%$ & $3.7 \%$ \\
Month & 74 & 61 & 40 & 6 & 7 & 1 & 189 \\
& Count & 74.0 & 61.0 & 40.0 & 6.0 & 7.0 & 1.0 & 189.0 \\
& Expected Count & $39.2 \%$ & $32.3 \%$ & $21.2 \%$ & $3.2 \%$ & $3.7 \%$ & $0.5 \%$ & $100.0 \%$ \\
& $\%$ within Health facility you patronise & $39.2 \%$ & & & \\
& $\%$ within Household Income per & $100.0 \%$ & $100.0 \%$ & $100.0 \%$ & $100.0 \%$ & $100.0 \%$ & $100.0 \%$ & $100.0 \%$ \\
\hline
\end{tabular}

\section{Chi-Square Tests}

\begin{tabular}{|l|c|c|c|}
\hline \multicolumn{1}{|c|}{ b } & Value & df & Sig. (2-sided) \\
\hline Pearson Chi-Square & 19.678 & 20 & .478 \\
Likelihood Ratio & 22.802 & 20 & .299 \\
Linear-by-Linear Association & 6.286 & 1 & .012 \\
N of Valid Cases & 189 & & \\
\hline
\end{tabular}

18 cells (60.0\%) have expected count less than 5 . The minimum expected count is .04 .

The pearson chi-square "P" value was obtained as 0.0478 which greater than 0.05 . Therefore there is no significant relationship between the health centre patronage and household income per month. Therefore the $\mathrm{H}_{0}$ (Null hypothesis) which stated that there is no significant relationship between the health centre patronage and household income per month was accepted. While the $\mathrm{H}_{\mathrm{i}}$ (Alternative hypothesis) which stated that there is significant relationship between the health centre patronage and household income per month was rejected.

Table 3: Cross tabulation of the major disease suffered in the last one year and Number of Room Occupied

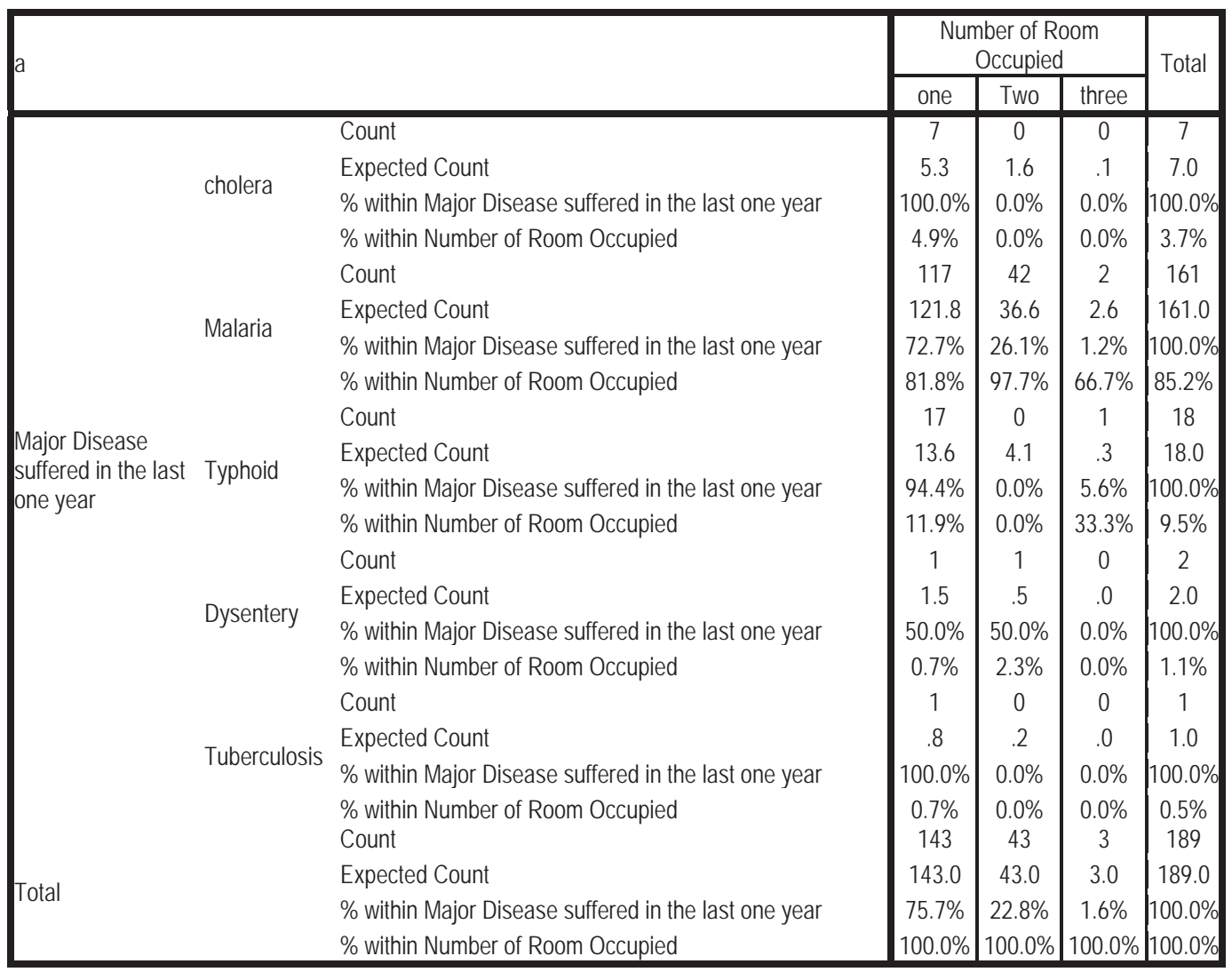




\section{Chi-Square Tests}

\begin{tabular}{|l|c|c|c|}
\hline $\mathrm{b}$ & Value & $\mathrm{df}$ & Sig. (2-sided) \\
\hline Pearson Chi-Square & 11.251 & 8 & .188 \\
Likelihood Ratio & 16.329 & 8 & .038 \\
Linear-by-Linear Association & .094 & 1 & .759 \\
N of Valid Cases & 189 & & \\
\hline
\end{tabular}

11 cells (73.3\%) have expected count less than 5. The minimum expected count is .02 .

The Pearson chi-square "P" value was obtained as 0.188 which greater than 0.05 . Therefore there is no significant relationship between the major disease suffered in the last one year and occupant per room. Therefore the Ho (Null hypothesis) which stated that there is no significant relationship between the occupant per room and major disease suffered in the last one year was then accepted. While the Hi (Alternative hypothesis) which stated that there is significant relationship between occupant per room and major disease suffered in the last one year was rejected.

\section{The Regression Analysis}

Some variable were subjected to regression analysis and the following were discovered.

Table 4: Descriptive Statistics

\begin{tabular}{|l|c|c|c|}
\hline & Mean & Std. Deviation & N \\
\hline Health Conditions & 2.1587 & .32327 & 189 \\
Physical Factors & 2.5168 & .41312 & 189 \\
Environmental Factors & 1.6393 & .23630 & 189 \\
Social Factors & 2.9974 & .77614 & 189 \\
\hline
\end{tabular}

Health condition of dwellers is the dependent variable, while the other variables were independents. The health condition variables include (major disease vector found in the house, major disease suffered in the last one year and health care facility patronized). The independent variables were classified into three broad categories namely: Social factors (which includes households income per month and household size), Environmental factors which includes (method of waste disposal, major sources of energy, treatment of water before drinking, distance of water from home and types of drainage facility) and Physical factors includes (types of apartment, age of building and wall materials).

Table 5: Correlations Analysis of some variables (physical factors, environmental factors and social factors)

\begin{tabular}{|ll|c|c|c|c|}
\hline & & Health Conditions & Physical Factors & Environmental Factors & Social Factors \\
\hline Pearson Correlation & Health Conditions & 1.000 & -.103 & $.205^{*}$ & $-.151^{*}$ \\
& Physical Factors & -.103 & 1.000 & .094 & -.054 \\
& Environmental Factors & .205 & .094 & 1.000 & -.044 \\
& Social Factors & -.151 & -.054 & -.044 & 1.000 \\
Sig. (1-tailed) & Health Conditions &. & .078 & .002 & .019 \\
& Physical Factors & .078 &. & .099 & .231 \\
& Environmental Factors & .002 & .099 &. & .274 \\
N & Social Factors & .019 & .231 & .274 &. \\
& Health Conditions & 189 & 189 & 189 & 189 \\
& Physical Factors & 189 & 189 & 189 & 189 \\
& Environmental Factors & 189 & 189 & 189 & 189 \\
& Social Factors & 189 & 189 & & 189 \\
\hline
\end{tabular}

${ }^{*}$ Correlation is significant at $5 \%$ level. Multiple correlation coefficient $(R)=0.281, R^{2}=0.079$.

There is an indirect correlation between the Health conditions and Physical factors as is shown in table 5. 0.078 is the "P" value since it is greater than 0.05 , there is no significant indirect correlation between health conditions and physical factors. Between health conditions and environmental factors since the "P" value equal to 0.002 which less than 0.05 , therefore there is significant direct correlation between health conditions and environmental factors. This implies that as 
the environmental factors improve health conditions also improve. Health conditions versus social factors since "P" value equal to 0.019 there is significant indirect correlation between the health conditions and social factors. Considering the variable that were made of social factors (households income per month and household size) when the income is increasing or improving there is propensity to spend which would leads to waste generated. Therefore the more the social factors the less the health conditions of dwellers. $\mathrm{R}$ is the multiple correlation coefficient, is the overall relationship between the health conditions and environmental factors, physical factors and social factors respectively.

The adjusted $\mathrm{R}^{2}$ is obtained at 0.079 ; this implies the amount of information accounted for by the independent variables about health conditions. The result shows that the information provided by the independent variables is not two strong, suggesting that they do not provide specific information about the actual health conditions. However, the model needs to be explained further than as it is in ANOVA table 6, hence the need for table 7.

Table 6: ANOVA

\begin{tabular}{|ll|c|c|c|c|c|}
\hline \multicolumn{1}{|c|}{ Model } & Sum of Squares & $\mathrm{df}$ & Mean Square & $\mathrm{F}$ & Sig. \\
\hline 1 & Regression & 1.556 & 3 & .519 & 5.305 & $.002(\mathrm{a})$ \\
& Residual & 18.090 & 185 & .098 & & \\
& Total & 19.646 & 188 & & & \\
\hline
\end{tabular}

a. Predictors: (Constant), Social Factors, Environmental Factors, Physical Factors

b. Dependent Variable: Health Conditions

Since the "P" value is equal to 0.002 which is less than 0.05 significant level. This information demands for the effect/ contribution of each factor, i.e environmental, social and physical factors on health conditions. This was carried out in the following regression analysis as shown in table 7.

Table 7: Regression Coefficients

\begin{tabular}{|ll|c|c|c|c|c|}
\hline \multicolumn{2}{|c|}{ Model } & \multicolumn{2}{|c|}{ Un-standardized Coefficients } & Standardized Coefficients & t & Sig. \\
\hline & & B & Std. Error & Beta & B & Std. Error \\
\hline 1 & (Constant) & 2.131 & .227 & & 9.404 & .000 \\
& Physical Factors & -.103 & .056 & -.131 & -1.850 & .066 \\
& Environmental Factors & .288 & .097 & .210 & 2.968 & .003 \\
& Social Factors & -.062 & .029 & -.149 & -2.108 & .036 \\
\hline
\end{tabular}

Dependent Variable: Health Conditions

The result in table 7 indicates that the calculated "P" value for environmental and social factors were 0.003 and 0.036 respectively. Since the "P" value is less than 0.05 then the environmental factors and social factors have significant effect on the health conditions of dwellers. Physical factors have no significant effect at $5 \%$ significant level on health conditions. Based on the result, it shows that environmental factors affect health conditions mostly. Therefore an environmental factor has strong direct effect on health conditions as indicated in the figure 1

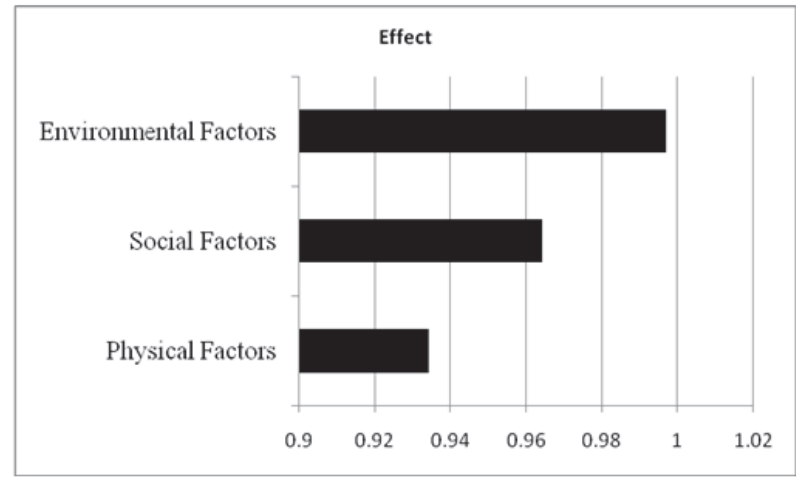

Fig 1: Effect of each variable using standardized coefficient 
The figure 1 shows the effect of each variable using standardized coefficient. The environmental factors have direct effect on the health condition of slum dwellers. The better the environmental conditions, the better the health conditions of the slum dwellers. This implies that the environment is a good determinant of health condition of slum dwellers. The social factors have significant effect on health condition of dwellers particularly the income per month and the household size. Likewise the physical factors which have to deal with building conditions in the study area have effect on the health conditions of dwellers

\section{Policy Guideline}

Although much progress and effort has been made in improving the quality of life of slum dwellers, the situation remains far from satisfactory from the health point of view (Zareena, 2011). Below are the summury guidelines of this paper.

* Proper environmental management is best key to avoiding the quarter of all preventable illnesses which are directly caused by environmental factors, there is an immediate need to tackle environmental health issues in slum areas in Nigeria and Africa as a whole to prevent the highly spread of communicable diseases.

* Problems such as unsafe water, sanitation and hygiene, and air pollution which are major contributors to the worldwide disease burden must be addressed by all the stakeholders concern in the built environment.

* There should be holistic approach to environmental health and institutional problems associated with working across disciplines including environment, health, education, energy, water, sanitation and hygiene which remain a challenge to government and non-governmental agencies in tackling environmental health in slum areas across the globe.

* Finally, while a total clearance of the slum in the study areas may not be feasible because of the cost elements, inconvenience and other logistic problems it might cause. It is evidence from the study that the level of deterioration is still redeemable. Programme like Urban Basic Service (UBS) which encompasses provision of facilities, environmental campaign will not only reduce the environmental health risks of slum dwellers but will also usher in a functional, livable and aesthetically pleasing environment.

\section{References}

Agbola, S.B (2005). Urbanization, Physical Planning and Urban Development in West Africa. Paper presented at the Agenda Setting Workshop of the Commonwealth Association of Planners (CAP) 2006 World Planner Congress Held between $14^{\text {th }}$ and $15^{\text {th }}$ November 2005 at the Millenium Hotel, Sokode Crescent, Wuze, Zone 5 Abuja.

Agbola, Nwokoro and Kassim (2007). Housing and Health in Agbola, Egunjobi and Olatubara (eds) Housing Development and Management 500-503 Malijoe Softprint Ibadan.

Carr, D. (2004). Improving the Health of the World's Poorest People Washington D.C Population References Bureau Retrieved from http//www.who.org on 12/5/2011 at 1.00am

Chen, N., Valente, P., and Zlotnik, H. (1998).What Do We know about Recent Trends in

Urbanization? In Migration, Urbanization, and Development: New Directions and Issues ed. By R.E. Bilsborrow, pp. 59-88. United Nations Population Fund (UNFPA). New York.

Mabogunje, A.L (2002). 2002 National Housing and Urban Development Policy: Catalyst for Mass Housing Delivery in Nigeria; Lead Paper Presented at the Second Abuja International Housing Summit Held at the Le Meridien Hotel Abuja.

Montgomery, M., and Ezeh, A. (2003). Urban Health in Developing Countries: Insights from Demographic Theory and Practice. Draft 2004. The Handbook of Urban Health. Kluwer Press, New York 2005.

Montgomery, M. R. and Paul, C. H. (2003). Urban Poverty and Health in Developing

Countries: Household and Neighborhood Effects. Policy Research Division Working Paper N0. 184. Population Council, New York City, New York.

Lagos state economic summit (2001). retrieved from http//www.lagosbureau.ng.com on 04/07/2011 at 1.30am

National Population Commission (2006): Census report in Nigeria. Collected from Lagos State NPC Office, Surulere.

Nwaka, G.I (2005). The Urban Informal Sector in Nigeria Towards Economic Development Environmental Health and Social Harmony. Journal of Global Urban Development 1 (1.) 14-17

Nwaka, G.I (2005). The Urban Poor, The Informal City and Environmental Health Policy in Nigeria. Journal of Global Urban Development. 2 (2) 5-7

Onyeche, .E (2011). ljora Badia: Slum for decades" Unpublished Article Retrieved from http//www.slumnigeria.org on 17/6/2011

Tenament Rate Department, (2011): Apapa Local Government Apapa Lagos State.

UNDP, (1997). Human Development Report to Eradicate Poverty. Retrieved from http://www. unhabitat.org on 13/04/2011 at 12.00pm

UN-Habitat Urban Indicators Program (2003). Global Urban Observatory and Statistics Databases. Retrieved from http://www.unhabitat.org on 13/04/2011 at 12.00pm 
Zareena, B. I. (2011). Environmental Health A Dissemination Paper Presented at The Centre of Excellence in Environmental Economic. Assessed from http//www.coe.mse.ac.in on 24/10/2011 at 1.15am. 